Japanese Yearbook on Business History - 2003 / 20

\title{
Institutional Fatigue in the Automobile Franchise System
}

\author{
Problems within the Sales Practice \\ of Giving Price Concessions
}

\author{
Hiromi SHIOJI \\ Kyoto University
}

T IS A WELL-KNOWN fact that the giving of price concessions has
become a normal practice in the business of selling automo-
biles. What is not so well known, however, is that many problems
exist in this practice. From all the evidence we have, there seems to
lie behind these problems an institutional fatigue in the automobile
franchise system itself. This study sets out to investigate the practice
of price concessions in automobile sales and the problems in the
modes of dealings connected with those concessions, and in the
course of such a study to extract the concrete forms in which the
institutional fatigue of the automobile franchise system shows itself.

PRICE CONCESSION SALES PRACTICES

The Actual Situation in Price Concession Sales

Section A of Table 1 presents the average price concession amounts and average price concession percentages for automobiles in differ- 


\section{TABle 1. What Happens in Price Concessions}

\section{A. By Automobile Price Range}

\begin{tabular}{lrr}
\hline Automobile Prices & APCA & APCP \\
\hline Under 1,500,000 & 14.8 & 13.6 \\
$1,500,000-2,000,000$ & 22.6 & 14.1 \\
$2,000,000-2,500,000$ & 22.5 & 10.8 \\
$2,500,000-3,000,000$ & 24.3 & 9.9 \\
$3,000,000-3,500,000$ & 22.8 & 8.7 \\
Over 3,500,000 & 27.9 & 7.9 \\
\hline Overall & 22.0 & 11.4 \\
\hline
\end{tabular}

B: By Maker

\begin{tabular}{lcr}
\hline Maker & APCA & APCP \\
\hline Company A & 25.7 & 13.2 \\
Imports & 24.0 & - \\
Company B & 22.9 & 11.3 \\
Company C & 22.3 & 11.3 \\
\hline
\end{tabular}

Source: Nihon Jidōsha Ryūtsū Kenkyūkai [Japanese Automobile Distribution Programme], "Jidōsha hanbai ni okeru nebiki, kakaku hyōji zesei mondai ni tsuite no bunseki to teigen" [An analysis of, and opinion concerning, the problem of price concessions and rectifying indications of prices in automobile selling], unpublished paper, 1995.

Note: The "Automobile Prices" column figures are in yen; the "APCA" (average price concession amounts) column figures are in 10,000 yen, and the "APCP" (average price concession percentages) column figures are in \%. These concession amounts and percentages relate to the base price of the vehicle. The four companies in Section B are those with the highest average price concession amounts.

ent price ranges. Except for the "Under 1,500,000 Yen" price range, all the average price concession amounts fall within the 200,000-to290,000 yen range. Though the "Over 3,500,000 Yen" price range gets the largest price concession, it is not true to say that, the higher the automobile price range, the higher the price concession given, because, for example, a higher concession is given in the 2,500,000$3,000,000$ yen price range than in the $3,000,000-3,500,000$ yen price range. And when we look at the percentages we see that they fall within the range of $7-15 \%$ and that price concessions as a percent- 
age of the total asking price get smaller and smaller the more expensive the automobile. When we then look at Section B of Table 1 we see the average price concession amounts and average price concession percentages of four automobile makers; their concession amounts fall within a range of 220,000-to-260,000 yen, and their percentages within an $11-14 \%$ range.

\section{The Existence of a Plurality of Prices (Price Indications)}

Next let us undertake to establish, before we go any further, the sort of price concessions that occur. In automobile (retail) sales there exist a plurality of prices (price indications). First of all there is the "(nationwide [regional]) suggested retail price" established by the automobile maker (hereafter, the manufacturer's suggested retail price)..$^{1}$ This is the price that appears in advertisements run by the automaker and in such public media as motorcar magazines.

Next there is the showroom list price that is shown by dealers on their own dealership premises and in their advertising brochures and the like. Since there are strict legal restrictions on resale price maintenance behavior, manufacturers are unable to place curbs on dealers in regard to showroom list prices. Dealers are free to price automobiles as they judge fit, and they have been required to indicate the "base price of a vehicle" of "a vehicle for standard use fitted out with standard equipment." 2

Now, even though dealers are free to price a vehicle as they judge

${ }_{1}^{1}$ The designations used for the various price indications have been formally determined by the "Fair Competition Agreement Concerning Price Indications in the Automobile Business" (hereafter, the Agreement) and the "Enforcement Regulations Concerning New Vehicles in Regard to the Fair Competition Agreement Concerning Price Indications in the Automobile Business" (hereafter, the Regulations). The designation "(nationwide [regional]) suggested retail price" is based on what is determined under Paragraph 2 of Article 19 of the Regulations: "When indicating prices in advertisements in newspapers, magazines, and the like," under "2) The Designations Given to Prices." See Jidōsha Kōsei Torihiki Kyōgikai [Automobile Fair Trade Council], comp., Jidōsha kōsei kyōsō kiyaku-shū: Heisei 8nen Ggatsu kaiteiban [Collection of automobile fair competition agreements: June 1996 revised edition] (Tokyo: Automobile Fair Trade Council, 1996).

2 With regard to a vehicle to which other than standard equipment or fittings have been added, it has been determined that the term "shop-front transfer cash price" be used to indicate the total of the base price plus the separately listed prices of each individual item of extra equipment. This is covered in Article 7 of the Regulations. 
fit, in Japan the normal practice is for dealers to establish a vehicle base price that is exactly the same as the manufacturer's suggested retail price. In most cases dealers do not announce any discount figures; all they indicate is the base price of the vehicle. In this situation the starting point for price concession negotiations is the base price of the vehicle. Still, in the case of certain types of vehicles, some dealers show, right from the start, not only the base price but also a discount price. This discount price may be called different names by different dealers; for example, it might be referred to as a "special price," or as a "bargain price." 3 The problem is, it very rarely happens that the vehicles are sold to the customers at those "special" or "bargain" prices. What usually happens is that the "special" or "bargain" price becomes the starting point for further price concession negotiations. Accordingly, there exists a third price, an "actual sale price" (or, seen from the perspective of the customer, the "actual purchase price"), which results from negotiations between a salesperson and an individual customer. This will be discussed in greater detail later, but the thing to be noted here is the fact that "actual sale (purchase) price" can differ from customer to customer, even in regard to vehicles of the same type and same use bought the same day at one and the same dealer. ${ }^{4}$

${ }^{3}$ Neither the Agreement nor the Regulations determine a specific designation for this kind of price: As regards the extent of any price concessions, under Paragraph 1 of Article 19 of the Regulations ("When indicating the price in documents handed over to the purchaser"), item b) states that "Whenever there is a price concession on the base price, on additional fittings or equipment, or on a special-use price," the dealer is required to indicate that amount. What should be noted here, however, is that "on documents handed over to the purchaser" after negotiations have been entered into with an individual customer and a price concession is granted, the dealer is obliged to indicate only "that amount", and there is no obligation to make public to all customers the price concessions that have actually been granted to previous customers.

${ }^{4}$ The first reason for differences in price concessions to different customers is a difference in customer negotiating power. The difference in customer negotiating power is a difference in the ability to mobilize to one's own advantage the competition among a number of dealers, an ability that is for the most part based on an ability to gather information. The second reason has to do with such things as the presence or absence of a trade-in vehicle, the number of optional parts being purchased, and the presence or absence of a loan contract. In negotiations over a price concession, a variety of means are used to make the price concession look large. One means is to give as a rough estimate of the price concession the amount of the trade-in value of the old vehicle. Another tactic is to establish as the base for negotiating a price concession the total price (the shop-front transfer cash price) that includes extras such as accessories 


\section{FIgURE 1. An Automobile's Price Structure (1)}

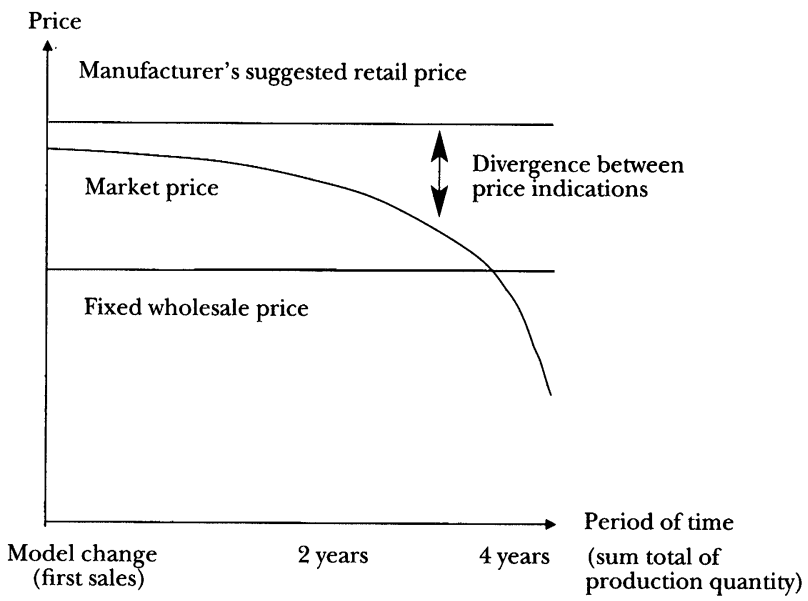

Sources: Figure 1 was produced on the basis of data personally collected by the author and by the author's research.

Note: This is only a schematic, or conceptual, diagram indicating relative positional relationships among the various price levels.

\section{What Is Meant by "Price Concession Sales"?}

Let us begin by studying the changes in prices (price indications) over time. In Figure 1 the vertical axis stands for the price of a single vehicle, and the horizontal axis shows the time period from the starting point of a model change (or of the first sales of a new model) through the course of the (roughly) four-year selling life span of that particular model. The time period represented by the horizontal axis also signifies, for the manufacturer, the sum total of that model's production quantity. We shall begin by looking at the features of three different prices.

and options, and to add any concessions on the extras to the concession on the base price. In this way, the amount of the price concession granted will differ from customer to customer. See, for example, Hirofumi Iwasawa, Gekkan jikayōsha tokubetsu rinjigō-fukyō mo buttobu! Kuruma nebiki hisshō-hō [The private automobile monthly (special issue): Out with the recession! A sure way to get the best vehicle price concession] (Tokyo: Naigai Publishing Co., 1998). 
First of all, the manufacturer's suggested retail price stays fixed until the next model change (normally a period of four years), and it never changes. Secondly, the wholesale price (or dealer invoice price) at which the dealer buys the vehicle from the manufacturer is normally set within the range of 80 to 90 percent of the manufacturer's suggested retail price; this price, too, will basically remain unchanged over the four years. We shall call this arrangement the "fixed wholesale price system." Thirdly, the market price, which is the average of the prices at which vehicles are actually sold to customers, starts out being not too far removed from the manufacturer's suggested retail price (or vehicle base price), but as the novelty effect of the model change weakens, this price gradually falls lower and lower. In recent years the novelty effect of a model change has not continued to last for long, with the result that the market price begins to fall at an earlier stage. As the time for the next model change approaches, a dealer will sometimes try to avoid being left with unsold stock by registering these vehicles in the dealership's name and then throwing them onto the market as shinkosha [lit., "new old cars" or "newsed cars," that is, cars that have never been driven yet are being sold as used cars]. In some cases, these vehicles have to be sold at less than the dealer invoice price.

Now then, what exactly do we mean by a price concession? Is it a price concession, for example, when a vehicle is sold below the manufacturer's suggested retail price as a result of the drop in the market price two years after a model change? The answer is no. There has been a fall in the market price, is all; the dealer has not reduced the price, the market has. When, for example, a real estate item that had been skyrocketing in price during the time of the bubble economy is sold in the recession of the 1990s at a greatly reduced price, nobody would call that reduced price a price concession by the seller. It is nothing but a drop in value-in other words, a fall in the market price..$^{5} \mathrm{~A}$ price concession, therefore, is strictly speaking understood to be the selling of an item below the market price.

${ }^{5}$ This is discussed in detail in an unpublished report of an organization called Nihon Jidōsha Ryūtsū Kenkyūkai [Japanese Automobile Distribution Programme] titled "An Analysis of, and Opinion Concerning, the Problem of Rectifying Price Concessions and Indications of Prices in Automobile Selling," produced by that organization in 1995. 
This having been observed, in this present study the term "price concession" will not be used in this strict sense of the term, but rather in the way it is customarily used in the automobile industry itself-namely, as the selling of a vehicle at a price that is lower than the manufacturer's suggested retail price (or base price) or lower than the "special/bargain" price itself. The reason for doing this is the need to offer a solution strategy for a problem for which a solution is presently being urgently sought, and to do this I felt it preferable to adopt a terminology that those seeking the solution feel more comfortable with, even though we have to remain aware of the fact that sometimes we are not dealing with price concessions in the strict sense of the word.

With these qualifications in mind, let us define price concession selling as the following practice: instead of indicating the price one really is willing to sell at, one indicates first of all a higher price (the manufacturer's suggested retail price/the base price, or sometimes a "special" price), then one negotiates a price individually with each customer and decides on a price in each individual case. Thus in this definition "price concession" is taken in the sense in which it is customarily used in the trade.

\section{Setting the Parameters}

What are the problems that we are talking about when we refer to the problems in price concession selling practices? First of all, we are not principally concerned with the problems arising from price falls, but with problems arising from price concession selling. We shall refer to falls in the market price (the extent and the manner of the falls, or the reasons for the falls) only when they have something to do with the price concession selling problems and with the mode of dealings between manufacturers and dealers. The reason is that falls in the market price are a problem that is determined basically by the relationship between demand and supply, which belongs to a different logical category altogether from that of price concession selling.

The aim of this study, then, is to see what exactly are the problems inherent in that method of price concession selling in which a higher price is indicated instead of the price the dealer is willing to 
sell at, and the dealer then negotiates with a buyer on an individual basis and arrives at an actual selling price on an individual basis.

These problems principally have to do with the mode of transacting a business deal that occurs between the dealer and the customer. Nevertheless, we do not set the parameters of this study only around such dealings between dealers and customers. Instead, we broaden them to include dealings between manufacturers and dealers, because these latter dealings are considered to be the cause of the price concession practices. By paying particular attention to the fixed wholesale price system and the method of compensating losses through rebates,${ }^{6}$ we propose to show how these affect price concession practices and to show the problems that they entail.

\section{THE PROBLEMS THAT OCCUR AT PRESENT}

\section{Divergences in Price Indications (Unfairness and Inconvenience)}

The first point I wish to make is the problematic nature of the way in which the showroom list price diverges from the actual sale price. This divergence entails two problems.

The first problem is the unfairness of the price indications. Let us have another look at Figure 1. There we see how the market price steadily falls not too long after the beginning of the sale of a model, and yet the manufacturer's suggested retail price (or base price) remains fixed at the one level. As a result, the divergence between the retail price and the market price (or actual sale price) keeps on increasing. Even if the dealer indicates a "special" or "bargain" price that he has pegged below the base price, it rarely happens that the vehicle is sold at that price. This is so because the "special price" is only the starting point for price concession negotiations, and the actual sale price diverges from the "special price" as well. Regardless of what price is considered, the action of indicating a high price that diverges from the actual sale price-that is, a high price that the dealer has no hope of getting in the real market-is itself in a certain sense unfair pricing. And this divergence inevitably follows

${ }^{6}$ In the automobile industry these are referred to as "incentives," but I call them rebates in order to achieve conformity with the terminology used in other industries. 
from the adoption of a price concession method based on negotiation rather than the straightforward indication of an actual sale price.

The second problem contained in the divergence entailed in the present price indication practice is the inconvenience to customers. Unless a customer visits the dealership and enters into price concession negotiations with a salesperson, the customer is unable to find out for certain what the actual sale price of a vehicle is. Is this not equivalent to forcing the customer to incur an unnecessary waste of the customer's time and energy?

If we look, for example, at what happens in the case of electrical household appliances, the method of giving price concessions based on negotiations that is used in the automobile trade is not used. Instead, we find that items for sale have two prices indicated: the manufacturer's suggested retail price, and a discount price. True, the divergence between the manufacturer's suggested retail price and the discount price is sometimes large, and this creates its own problem for people in that trade. ${ }^{7}$ But it rarely happens that the discount price indicated for the item is the starting point from which a further price concession is given to a customer as a result of individual bargaining. Even if a further concession is given, it will be a small one, and often it is an amount that is directed to salespersons by a sales manager beforehand rather than the result of bargaining. In other words, in the case of electrical household appliances, the divergence between the actual sale price and the discount price shown on the price tag is small, and as a result there is thought to be minimal inequity and unfairness in the pricing and sales practices of traders in that line of business.

${ }^{7}$ The problem involved in the pricing of electrical household appliances is that the manufacturer's suggested retail price is set far higher than the actual sale price. Indeed, the former price is so far removed from the market price that it has practically no meaning as far as providing reliable information to consumers regarding the price of an item. This extreme divergence went on for so long in the trade that the Fair Trade Commission of Japan finally stepped in and provided administrative guidance, with the result that there has been a partial adoption of an "open price" (which means that manufacturers do not set the manufacturer's suggested retail price). In some other industries (for example the construction machinery industry), business discussions start from a figure that is "hanne no hachikake" (that is, " $80 \%$ of half price", i.e., $40 \%$ of the manufacturer's suggested retail price). 
Differences among Purchasers in the Actual Purchase Price (Unfairness and Inequity)

Another problem is the way actual purchase prices differ from customer to customer. Among customers who have purchased a vehicle of exactly the same type and the same use on exactly the same day from the very same salesperson at one and the same dealership, the negotiations that go on behind closed doors with each one of them can end up in differences of as much as two or three hundred thousand yen in the prices they pay.

Figure 2 is a conceptual diagram of actual purchase price distribution. When a customer begins negotiations at a dealer's showroom, the salesperson immediately offers a price concession of a fixed sum of money. Consequently no customer actually purchases a vehicle at the vehicle base price, and there are few who purchase a vehicle at the "special price" that is given on the dealer's price tag or in the dealer's advertising leaflets. Still, the amount of price concession that the salesperson first offers can be (and often is) below the price concession ceiling imposed on the salesperson by his/her superior. Some customers accept this first offer and decide to purchase the vehicle. Of those customers who push on with negotiations, some succeed in getting the price knocked down as far as the ceiling on concessions imposed on the salesperson. Customers who have stronger bargaining power, however, keep negotiating and get as far as the concession ceiling imposed on the top decision maker in the showroom, the manager. And, finally, there are a very few customers who have the bargaining power to get as far as the ceiling that requires approval of the head of the dealership's head office. This is how it comes to be that the amount of price concession varies from customer to customer.

Be that as it may, for there to be such differences among customers in the amount of money they pay when they purchase a mass-produced industrial product under the same conditions (at the same time, made for the same use, etc.) is, in a certain sense, inequitable and an unfair sales practice. ${ }^{8}$ The major reason why a

8 There are those who argue the opposite, that it is only natural that actual purchase prices should differ among customers who have invested different amounts of money and energy and consequently have different bargaining powers. It would be inequitable, they argue, if somebody who invests nothing and puts no effort whatso- 


\section{Figure 2. Actual Purchase Price Distribution}

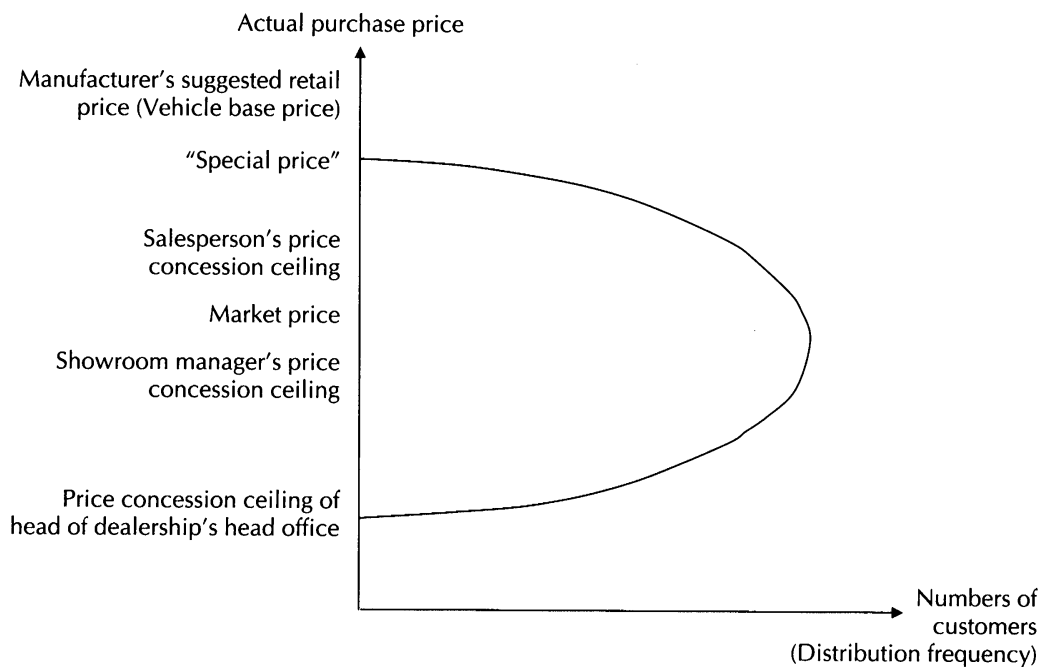

(Sources and note the same as for Fig. 1.)

one-price system (which means that once a price has been announced for a certain day, or week, or month, no vehicle can be sold for less than that price to anybody) was introduced in the United States in 1990 was the large increase in customer dissatisfaction over the differences from one customer to another in actual purchase prices. The pervasiveness of customer dissatisfaction was brought to light through a survey of people who had just purchased an automobile, a survey that revealed 70 to 90 percent of the customers felt unhappy because they "couldn't buy the car at the lowest price" because of

ever in looking for a good deal ends up paying exactly the same price as someone who buys several automobile magazines and does his homework on automobile prices and then goes and enters into negotiations with several dealers. For more on this viewpoint, see Hiromi Shioji's discussion of reformation trends in price concession sale practices in Jidōsha ryūtsū no kokusai hikaku: furanchaizu shisutemu no saikakushin o mezashite [The Structure of Automobile Distribution: An international comparison] (Tokyo: Yūhikaku, 2002), chap. 10. 
their timidity, lack of confidence, and so on. This led to the adoption of the one-price system, which means that a dealer right from the start displays a price that has been lowered to a level approaching the market price, and once that has been done no bargaining over the price is allowed. This is an attempt to eliminate the inequitableness and unfairness that was engendered by the older price concession selling method.

\section{A Drop in Market Price Level When Word Gets Around Concerning Extravagant Price Concessions}

Dealerships, showroom managers, and individual salespeople who do not have strong marketing leverage, and who are working under pressure to meet excessively high sales targets, are forced to make excessive, and on occasion extreme, price concessions that dealerships, showroom managers, and salespeople with strong marketing leverage do not need to make. If the present price concession practices did not exist (if, for example, a one-price system were in place), there would most likely be no such excessive or extreme price concessions. Under the present system, however, such concessions do at times occur, and when they do, they do not adversely affect only the profits of the dealers who make such concessions. Because of the fact that news of such extravagant price concessions gets into automobile magazines and spreads far and wide through the market, such concessions also have an adverse effect on the price concessions other dealers offer. This in turn leads to a vicious circle of even greater price concessions that drag the market price down everywhere.

\section{The Inequity of the Burden of Risk Involved in Market Price Fluctuations}

If we look at the wider picture so as to include the arrangement between manufacturers and dealerships, we will find more problems involved in the price concession system (Figure 3). We see that, even when the market price has fallen, the wholesale price that the dealer pays to the manufacturer is fixed. What we mean by "fixed wholesale price" needs some explanation, because there are several variations included in the term.

One variation occurs when a new model turns out to be unpopu- 
lar and its market price drops rapidly; in such a case the manufacturer might add a particular feature (a navigation system, for example) that converts the vehicle from a standard to a special category, yet sell it to the dealer at the same price as a standard vehicle-thus in effect lowering the wholesale price to the dealer.

Another variation occurs when a new model is enjoying fairly good sales but the manufacturer introduces a minor model change or develops a derivative model with a new use; in such cases the manufacturer will absorb the costs of development and other production costs and will sell these variant models to the dealer at the same price as the original new model-again, in effect selling them to the dealer at lower than the wholesale price. Finally, once the timing of the next model change has been determined, the manufacturer might lower the wholesale price just before the change takes place, in an effort to clear away all the old models. When we use the term "fixed wholesale price system" to refer to the arrangement between manufacturers and dealers, therefore, we are including all these exceptional measures within the term. ${ }^{9}$

In Figure 3 the difference between the market price and the fixed wholesale price represents the dealer's gross profit. It is immediately obvious that, as the market price falls, the dealer's gross profit keeps shrinking. If the dealer is forced into registering vehicles and selling them as "new used cars" when a model change is about to take place, it is possible that the dealer will have to sell below the wholesale price-will incur a loss, in other words (we are eliminating here any consideration of rebates made by the manufacturer to the dealer). This means that the dealer is shouldering the entire burden of risk involved in market price fluctuation.

What about the manufacturer's gross profit? If other conditions remain equal, the manufacturer's manufacturing cost goes down as a result of what is called the learning effect and the result of economies of scale. ${ }^{10}$ In Figure 3 on the following page the differ-

${ }^{9}$ Another point worth noting is that there is absolutely no volume discounting in the wholesale price within the automobile franchise system.

${ }^{10}$ Things like a fall in the manufacturing cost as a result of the learning effect, or a fall in the purchase price of parts, can be listed here as elements in the fall of the manufacturing cost. This curve in manufacturing cost assumes a neutral situation in which there is no large discrepancy between the number of vehicles actually sold and the 
FIgURE 3. An Automobile's Price Structure (2)

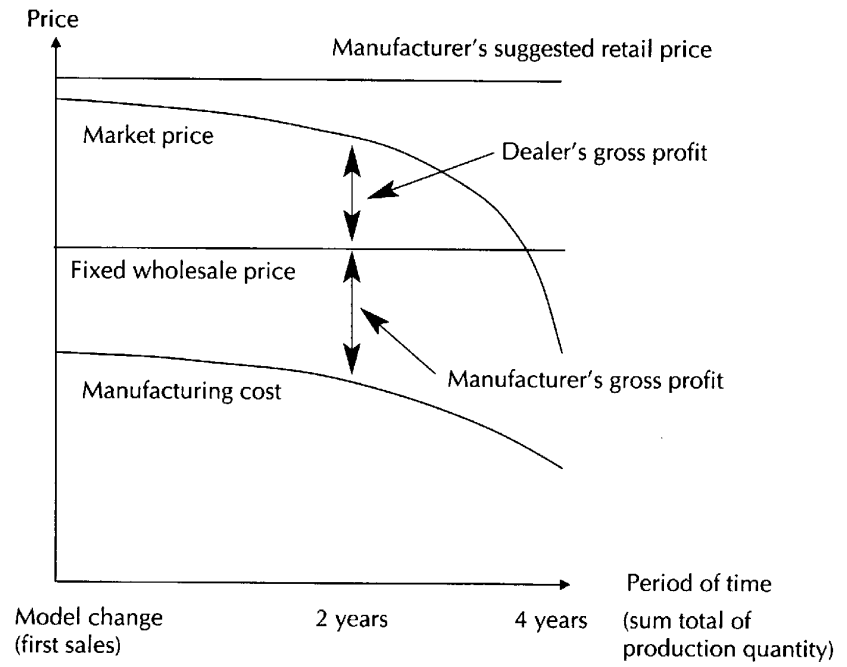

(Sources and note the same as for Fig. 1.)

ence between the fixed wholesale price and the manufacturing cost is the manufacturer's gross profit. It is obvious that, the longer a model keeps selling (and hence the larger the number of vehicles of that model produced), the greater the gross profit of the manufacturer. ${ }^{11}$ Whereas the dealer's gross profit falls in proportion to the fall in the market price, the manufacturer's gross profit keeps

numbers expected to be sold in the original planning stage. If the number of vehicles actually sold falls much below the levels expected in the planning stage, the curve shown in Fig. 3 can describe an arc rising upward on the right side.

${ }^{11}$ The manufacturing cost is calculated by adding the production costs of the division directly involved in manufacturing the model to development expenses and dividing by the number of vehicles produced. Thus the manufacturer's gross profit discussed here refers to the contribution margin per vehicle. Hence the gross profit we are looking at here is not the operating profit base calculated by adding the indirect costs of the head office and so on (the joint fixed cost) to the manufacturing cost and subtracting these costs from sales. This is done for comparability, since the dealer's gross profit to which we are comparing the manufacturer's gross profit is not the operating profit base obtained by subtracting the dealer's operating expenses from the dealer's gross profit (sales minus cost of sales), but simply the gross profit from sales. 
steadily increasing without any direct relationship to market price trends. ${ }^{12}$ This means that manufacturers are not taking on the risk of market price fluctuation in the same way that dealers are. The principal way the former cover the latter's risk is by partially compensating the latter's losses through rebates. Consequently, in this arrangement it is natural for there to be strong motivation on the part of the manufacturers to get dealers to sell as many vehicles as possible, and to force dealers to take many vehicles from the manufacturer even if it means rebates have to be increased a bit more. ${ }^{13}$

Here it is easy to find the factors behind the manufacturers' attempts to force the dealers to accept as many vehicles as possible: the building in of a supply pressure mechanism and the acceleration of a fall in prices resulting from that mechanism. We can add that it is a fact that the acceleration of a fall in prices has acted as a

${ }^{12}$ It cannot be said that there is absolutely no connection between market price fluctuation and the manufacturer's gross profit, because a fall in the market price implies a slump in sales, and since the manufacturing cost includes the fixed expense of development funding, when the number of vehicles sold (and consequently the number of vehicles produced) slumps, the manufacturing cost per vehicle will increase. But, as was mentioned in note 10, the assumption underlying Fig. 3 is that there will not be a large difference between the number of vehicles sold and the number of vehicle sales projected in the planning stage, and under this assumption the manufacturing cost curve will not rise on the right side. For this reason, in the abstract it is impossible for there to be a reduction in the manufacturer's gross profit. Nevertheless, since in the real world it is possible for a manufacturer to have rosy expectations and set the number of expected sales too high, with the result that the number of actual sales falls far below expected sales, in the real world it is not unusual to have instances of a manufacturing cost describing a rising curve that shows a decreasing manufacturer's gross profit. If one adds to this the fact that, even though development expenses in the case of minor model changes and derivative models are additional costs, the manufacturer maintains the wholesale price figures, the result will be that there will be many negative factors eroding the manufacturer's gross profit if there is no proportionate rise in the number of vehicles sold. Thus manufacturers say that, under such conditions as these, the contribution margin from the several different models being sold by them decreases with the passage of time in each model's life span of approximately four years.

${ }^{13}$ One pillar of the Toyota production method is the automatic stop reaction built into the automation, whereby the equipment or operation stops as soon as something abnormal occurs or a defect is detected. And when trouble occurs, there is also built in a mechanism to make the people on the job, and their supervisors, sweat blood until the trouble is eliminated. With the fixed wholesale price system, however, the mechanism at work in the aggressive sales of vehicles that are for the most part unsellable in the market, is a mechanism that, far from making the manufacturer sweat blood, in the short term, at least, rewards the manufacturer with increasing profit. 
hotbed for breeding price concession methods. These have been produced by the fixed wholesale price system and led dealers down the path of long years of low profits.

Let us consider, from the perspective of the ability to adapt to market trends, the problems that this fixed wholesale price system entails. As a sort of generalization, we can say that in the United States the relationship between the market (dealers) and production (manufacturers) has been one in which the automakers have a strong tendency to push their products onto the dealers; until recent years, they accepted no vehicle orders from dealers beforehand and instead forced on the latter the vehicles they produced in their plants in speculative numbers. This is the basic policy they have followed when drawing up production plans. In Japan, on the other hand, automakers have tended to pull rather than push; that is, they have a history of linking actual orders coming in from customers and/or dealers with speedy production of the vehicles desired and of refining the order entry system in minute detail while adopting it in their daily assembly plans. ${ }^{14}$ There has been a strong tendency to introduce the "pull principle" (which is the principle at work in the kamban method) between the dealers (= subsequent stations) and the manufacturer (=previous station). The result is that at Toyota Motor Corporation, which is the best example of such a manufacturer, the vehicles that move along the assembly lines are basically all being produced in response to orders from dealers, of which about $60 \%$ are based on orders from customers. Thus automakers in Japan are more capable than their U.S. counterparts of making flexible decisions about what to make (which models, what uses), how many to make, and when to make, in speedy responses to changes in the market.

And yet, when it comes to deciding the price at which to sell the car to the dealers, the same automakers are unable to respond speedily to market changes (fluctuations in the market price). They still hold fast to a method that fails to display sufficient flexibility.

\footnotetext{
${ }^{14}$ See H. Shioji, "Waido serekushon-ka jitsugen kikō no keisei" [The development of the wide-selection production system by Toyota in the 1960s], Keizai ronsō [The Economic Review] (Kyoto University), 141, no. 1 (1988); and Hirokimi Okamoto, Gendai kigyō no sei-han tōgō [Integration of production and sales in modern enterprise] (Kyoto: Minerva Shobō, 1995).
} 
(The same thing holds true in the United States.) This method is the fixed wholesale price system, one of the pillars of the automobile franchise system. The institutional fatigue in the franchise system shows up clearly in this, one of its pillars.

One might well wonder how wholesale prices are set in other businesses. Let us compare this system with what is done in the electrical household appliance business. In the past, comparisons between the automobile and the electrical household appliance businesses often focused on the exclusive sales system and the territory system. But overlooked in past studies has been the manner of deciding this wholesale price. The electrical household appliance trade decides the wholesale price differently from the automobile trade. Electrical household appliance manufacturers decide the wholesale price through negotiations with mass retailers of those appliances. During the life span of a certain model, revisions of the wholesale price in response to movements in the marketplace take place extremely often. On the other hand, in dealings with electrical household appliance outlets within their own keiretsu group, the manufacturers unilaterally decide what the wholesale price will be. This wholesale price is reviewed by the manufacturer in response to market fluctuations, but not as often as happens with the mass retailers.

In the automobile business the automakers determine the wholesale price (also called the invoice price) unilaterally. The contracts between manufacturers and dealers all include the clause "The invoice price of the products exchanged between Part A and Part B will be decided by Part A" (where Part A refers to the manufacturer, Part B to dealers). ${ }^{15}$ Furthermore, as has already been pointed out, this wholesale price is fixed for the life span of each particular model, and it rarely happens that it is changed.

${ }^{15}$ For more details on these contracts, see Kazumasa Akita, "Jidōsha" [Automobiles], in Saishin hanbaiten keiyaku handobukku [The latest handbook of retailer contracts] (rev. ed.), ed. Kenji Kawagoe (Tokyo: Bijinesu Sha, 1986); K. Akita, Keiretsu torihiki to hōkisei [Keiretsu dealings and the legal system] (Nagoya: Aichi Shobō, 1994); and Shigehiro Aritomi, Jidōsha ryūtsū no jisshō bunseki [A positive analysis of automobile distribution] (Tokyo: Shinhyōron, 1979). Some dealers in the United States criticize such a clause for being an unfair contract. See Art Spinella, Beverly Edwards, Mo Mehlsak, and Larry Tuck, America's Auto Dealer: The Master Merchandisers (Van Nuys, Cal.: Freed-Crown Publishing Co., 1978). 


\section{Figure 4. Price Structure of Electrical Household Appliances}

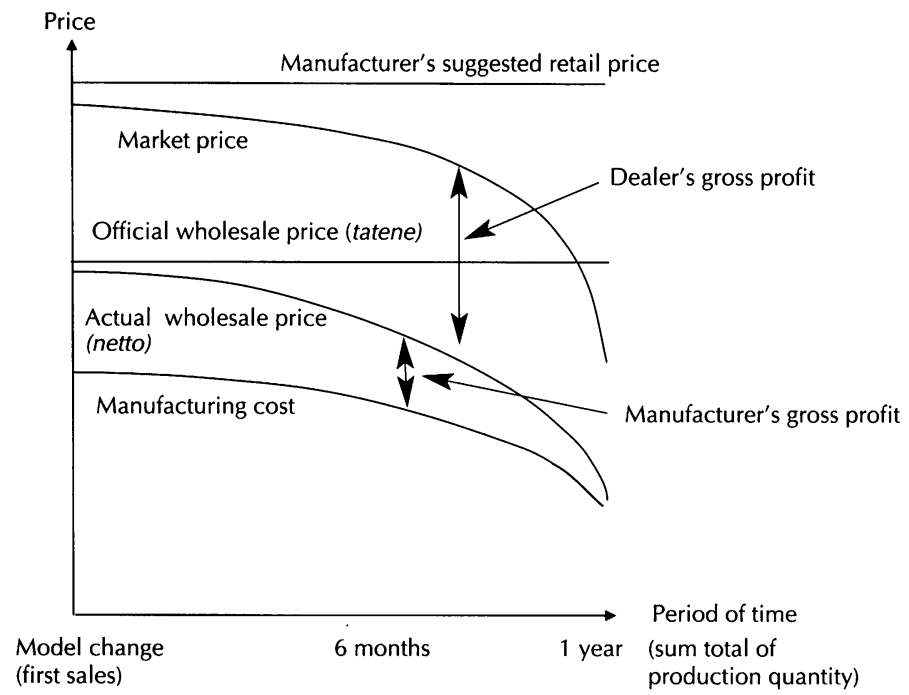

(Sources and note the same as for Fig. 1.)

Figure 4 can be used to explain the manner in which wholesale prices are determined in the electrical household appliance trade. First of all, note that, just as in the automobile trade, the manufacturer's suggested retail price is decided at the time of the first sale of a new model, and this price does not change. Secondly, note that, as in the automobile trade, the market price of electrical household appliances starts falling after the products have been on the market for a while. But whereas the selling life span of an automobile model is normally four years, that of an electrical household appliance is frequently less than one year. Thirdly, the official wholesale price at which the manufacturer sells to mass retailers, a price that is something of a formality, is called a tatene, or official quotation; note that, as in the case of the automobile trade, this price is determined unilaterally by the manufacturer, and it stays unchanged during the selling life span of the model. Fourthly, note that, in the case of 
electrical household appliances, there is a separate wholesale price that is decided through negotiations between the manufacturer and each of the mass retailers, and this price, which is the actual wholesale price, is reviewed frequently. This actual wholesale price is a (wholesale) market price that includes volume discounts and rebates, and it is referred to in the trade as the netto.

What happens in the negotiations on actual wholesale prices (the first agreement on a price and later revisions) as it is carried out between the manufacturer and a mass retailer? First of all, the most important factors prompting both sides to discuss the level of the actual wholesale price (the netto) are:

1. the sales record of the product (at the time the model just comes out this would be the product's expected sales record) and

2. retail price trends in the market.

Then an agreement is made in regard to a volume discount that is based on the quantity being purchased by the mass retailer. Large general merchandising stores like Daiei, for example, ask for a discount that corresponds to the quantity it purchases for its outlets all over the country. Finally, both parties negotiate the amount of rebate(s) the manufacturer will give the mass retailer. Now, while it is true that the manufacturer has already formulated its own norms for dispensing rebates, it allows leeway for negotiation on the part of the mass retailer in regard to how it will actually dispense them. The actual wholesale price between a manufacturer and a given mass retailer will be determined through a process of negotiation on the above points. ${ }^{16}$

Such negotiations with mass retailers take place once every one to three months in the beginning, then once a month as soon as market prices start moving down quite considerably, and then in shorter intervals just before a new model is going to be introduced. Thus it is obvious that the electrical household appliance trade is able to respond more quickly, with greater flexibility, to market

${ }^{16}$ The process of formulating an actual wholesale price as carried out between the manufacturer and a retailer within the keiretsu group is basically a process that is independent of what occurs in the negotiations with mass retailers, and without regard for the four factors that are considered in negotiations with the latter. 
fluctuations than the automobile trade. Seen from the perspective of the price concession problem, one of the advantages of such a mass retailer system found in the electrical household appliance system is that, as the actual wholesale price moves down, the gross profit of the appliance manufacturer also goes down. There is less potential, in other words, for the supply pressure that one finds in the automobile trade. ${ }^{17}$

\section{The Unilateralness of Determinations to Give Rebates and the Retroactive Nature of Establishing How Much of a Rebate to Give}

The granting of rebates to dealers as a means of encouraging sales is a normal practice among automobile manufacturers in Japan. The practice offsets to some extent the unilateralness of the risk burden engendered by the fixed wholesale price system, and it also compensates for reduction in the dealer's gross profit. From what is compiled in Table 2, we see that the manufacturers devoted between 14 and 27 percent of their gross profit from sales to rebate-related costs, that in the case of three of them these costs exceeded their operating profits, and that the rebate-related costs average out at 50,000 to 110,000 yen per vehicle.

Does this mean that the inequitableness of the risk burden resulting from market price fluctuations is eliminated by the injection of such rebates into the scheme of things? Clearly, the inequitableness is alleviated to some extent. ${ }^{18}$ Still, the following two problems can be raised in connection with the problem of price concessions. The first is that the granting of a rebate is unilaterally decided by the manufacturer. In the electrical household appliance trade, as we

${ }^{17}$ I am not maintaining that the system used in dealings with electrical household appliance mass retailers is effective under any and all conditions. I believe that the system is more efficient as a form of transaction and as a framework for transaction governance than the fixed wholesale price system under conditions in which market prices fall rapidly. This opinion does not necessarily hold for other conditions. The system, by the way, is called in more technical terms a "fluctuating wholesale price system." For more details on the subject, see Shioji, The Structure of Automobile Distribution (cited in note 8 above).

${ }^{18}$ I must leave for a future time a demonstration of the exact extent to which such rebating compensates for profit losses suffered by dealers as a result of falling market prices. For the moment let it suffice to point out the average price concession per vehicle of 220,000 yen shown in section A of Table 1, as against the rebate-related cost range of 50,000 to 110,000 yen per vehicle shown in Table 2 . 
TABLE 2. Rebate-Related Costs (1995)

\begin{tabular}{lcccc}
\hline & $\begin{array}{c}\text { R-R C } \\
\text { (100 million yen })\end{array}$ & $\begin{array}{c}\text { Percentage of } \\
\text { R-R C to Gross } \\
\text { Profit (\%) }\end{array}$ & $\begin{array}{c}\text { Operating Profits } \\
(100 \text { million yen })\end{array}$ & $\begin{array}{c}\text { R-R C per Vehicle } \\
(10,000 \text { yen })\end{array}$ \\
\hline Toyota & 1,639 & 17.3 & 2,353 & 8 \\
Nissan & 1,153 & 20.8 & 400 & 11 \\
Honda & 401 & 14.6 & 440 & 5 \\
Mitsubishi & 865 & 26.2 & 624 & 11 \\
Mazda & 384 & 24.6 & -126 & 10 \\
\hline
\end{tabular}

Source: The financial statement conspectuses of each company for the year 1995.

Note: 1 . The figures for rebate-related costs (R-R C) appear in financial statement conspectuses under the headings "Sales Costs" (Toyota, Nissan), "Sales Encouragement Money" (Honda), "Sales Promotion Expenses" (Mitsubishi), and "Sales Encouragement Expenses" (Mazda). Everything included under these headings is not necessarily granted as rebates to dealers in Japan itself. Also, the range covered by each of these headings is considered to differ from company to company. Nevertheless, because these headings are not broken down further into more detailed items, I believe these figures give a summary picture of the scale of each company's related expenditure for items including rebates.

2. The percentage of $\mathbf{R}-\mathbf{R} \mathrm{C}$ to gross profit is the proportion of rebate-related costs as a part of gross profit.

3. The figures for rebate-related costs per vehicle were obtained by dividing the number of vehicles that each company sold domestically into that company's R-R C.

saw, manufacturers formulate their own policies regarding the disbursement of rebates, but they leave room for negotiations over how rebates are distributed, and the matter is an item on the negotiating table with mass retailers. In the automobile trade, however, a manufacturer takes into consideration movements in the market and in the dealer's business situation, and then makes a decision based on his own judgment, whether to give a rebate or not. From the viewpoint of achieving his marketing strategies, this suits the manufacturer better because things go more smoothly when the manufacturer makes unilateral decisions. But this allows room for a manufacturer's arbitrariness to become factored into the process. At times when the manufacturer is more interested in sales vol- 
umes and market share than profitability, rebating will take place in relatively large volumes, but when there has been a shift in strategy, rebating will shrink. As a result, the dealer is at the mercy of the manufacturer's rebate policies and faces a certain amount of difficulty when it comes to maintaining his own long-term sales strategy.

The second problem arises from the fact that the amount of the rebate is not known until after the fact, or retroactively. In the electrical household appliance trade, where the great majority of manufacturers use "purchasing rebates," the amount of the rebate(s) is settled (which means the netto, or actual wholesale price, is also settled) at the time the retailer has decided on the quantity to be purchased from the manufacturer. As a result, the unit purchase price can be established.

In the case of the automobile trade, however, "purchasing rebates" are not used, and instead rebates are granted on the basis of the number of vehicles registered; the amount of the rebate(s) depends, thus, on whether or not vehicles have actually been sold. The amount of the rebate(s) is calculated on the basis of the number of vehicles the dealer has sold to customers and registered at the District Transport Bureau. The amount of the rebate(s), therefore, is settled only after the fact, and it is only after the rebate money is factored in that the dealer is able to establish how much the unit cost of each vehicle he purchased was. ${ }^{19}$

The rebate situation is made even more complicated by the different types of rebates on offer. In the automobile trade the largest rebate, accounting for $66.2 \%$ of the total, is the rebate for achieving vehicle number targets (mokuhyō daisū tassei ribēto), followed by the rebate for increasing market share (shijō senkyoritsu kakudai ribēto) at

\footnotetext{
${ }^{19}$ In the course of gathering information on the electrical household appliance trade, I was deeply impressed by the words of a person in charge of purchasing who was working for a mass retailer: "The way it's done with autos, you don't know until later what the purchase price is. We could never do that with household appliances; it'd be too scary!" This is not to say that there are compelling economic reasons for determining the purchase price at an early stage in every industry. There are industries like the petrochemical industry, for example, in which, because of the big swing in crude oil prices and the sharp fluctuations in exchange rates, decision are made in regard to the types and quantities of products at the time contracts are signed, but prices are determined several months later when the products are delivered. In such cases, both parties aim at a mutual sharing of risks.
} 
$14.7 \%$ (the remaining $19.1 \%$ of the rebates being for such things as fleets, trade-ins, old models, and being in a priority region). ${ }^{20}$ The amount of the rebate given for achieving vehicle number targets is based on a graduated scale, so that the amount per vehicle depends on the number sold (the more sold, the higher the rebate per vehicle). As a result, the dealer will not know how much the rebate per vehicle will be until at the end of the allotted period of time. When it comes to the rebate for increasing market share, however, the dealer will not know if he will get a rebate or not until later, because even after his selling period is over and the number of vehicles he sold has been tallied up, he still has to wait until the figures from other dealerships have been made public. So this rebate is much more dependent on externality and is delayed longer than the other one. In the most extreme cases, the manufacturer may not decide the norms regarding the amount and percentage of the rebates ahead of time, but only at the end, after the allotted sales period has ended.

In the various possible scenarios described above, what come across as common threads running through all of them are the inability of the dealer to know the amount of the rebate(s) until after the event, the inability of the dealer to establish the real purchase price of a vehicle except retroactively, and the way the dealer's profits are at the mercy of the manufacturer's discretion in granting rebates of various kinds.

What are the effects, then, of this situation? The first effect is to make it extremely difficult for a dealer to draw up any profit plan. Figures become highly speculative and conjectural. The second effect is that, because the dealer is operating without a clear idea of the real purchase price of the vehicle he is selling to the customer, without a clear idea of how far he can give a price concession before he will lose on the deal or end up with no profit at all, he is forced to make haphazard guesses as he increases a price concession and, in some cases, maybe an excessive one. The third effect is that, because the real purchase price for each vehicle cannot be established ahead of time, changing to a one-price system in which there is a small gross profit for the dealer built into the system is unwork-

${ }^{20}$ Office of the Fair Trade Commission, Jidōsha no ryūtsū jittai chōsa [A survey of automobile distribution] (Tokyo: Office of the Fair Trade Commission, 1993). 
able, and so it is difficult for the dealer to break out of the price concession sales method. The fourth effect is that it is an impediment to gross profit orientation aimed at raising a dealer's profits by putting a higher value on that gross profit and ensuring that it is achieved in the dealer's retail sales to customers. The fifth effect is that it breeds an orientation in a direction opposite to that of ensuring a dealer's gross profit-an orientation to rebate dependence that aims at making up for losses resulting from price concessions by selling more and more vehicles by means of yet other price concession sales and securing rebates that way, and hoping to raise profits by means of rebates. ${ }^{21}$

To sum up, on the one hand the fixed wholesale price system has a supply pressure mechanism built into it, it accelerates price falls, and it forms a hotbed for price concession sales; on the other hand, the system of compensating losses through rebates, which is used to alleviate the inequitable burden of risk engendered by that fixed wholesale price system, intensifies price concession sales and becomes a key factor in the production of a structure that leads to low profits for dealers.

\section{Increased Cost Involved in Negotiations between Customers and Dealers}

In comparison with the problems already pointed out, this one may seem relatively minor, but we should not overlook the cost involved in the time spent both by the customer and by the salesperson in the price concession negotiation process. This becomes significant when the salesperson, or the customer, makes several trips back and forth between the dealer's showroom and the customer's home to haggle over the last ten or twenty thousand yen in the deal. While no positive figures are available regarding how much time is involved in how many cases, one thing is sure: both the customer and the salesperson are being forced to waste a lot of time on this type of activity.

The above discussion has indicated six points that are problematical in the present practice of price concession sales. From what has

${ }^{21}$ There can be no denying that retroactive, graduated rebates are a powerful stimulus to competition. But in present circumstances, where market prices fall rapidly and price concession sales are rife, such rebates have the huge disadvantage of destabilizing the business operations of dealers. 
been said, it should be patently clear that there are signs of institutional fatigue in the automobile franchise system.

* This paper is a condensation, with some revision, of the author's The Structure of Automobile Distribution, chapter 9 (cited in note 8). 